\title{
Género y mirada: la invisibilización del conocimiento producido por las mujeres en México
}

\author{
Gender and gaze: the invisibility of knowledge \\ produced by women in Mexico \\ José Ricardo Gutiérrez Vargas \\ Centro Regional de Investigaciones Multidisciplinarias/ \\ Universidad Nacional Autónoma de México, Ciudad de México, México \\ jr.gutierrez@crim.unam.mx \\ https://orcid.org/o0oo-000I-8124-8013 \\ ISSN-OI85-4259; e-ISSN: 2007-9176 \\ DoI: http://dx.doi.org/I0.28928/ri/922022/aoti/gutierrezvargasj
}

\begin{abstract}
Resumen:
Este trabajo establece un vínculo entre género y representación para examinar el sustrato moderno-colonial de una mirada epistémica que tiende a invisibilizar los conocimientos producidos por las mujeres y a cancelar su papel como sujetos cognoscentes. Para hablar del asunto se analiza, bajo la categoría "colonialidad del ver", la representación construida por la exposición “Feminicidio en México" (2017) del Museo de la Memoria y Tolerancia de la Ciudad de México, sobre un grupo de mujeres activistas de la periferia urbana. Dicha aproximación facilita observar cómo el uso curatorial de un conjunto de fotografías desencadenó una injusticia epistémica que excluyó las voces de estas mujeres del campo de saber/poder configurado por la exhibición. Así, el artículo propone que el reconocimiento colectivo del valor de la vida de las mujeres, en el contexto mexicano de las violencias feminicidas, radica en las formas en que esas vidas son relatadas y reconocidas, públicamente, desde lo que revela su acción y su palabra.
\end{abstract}

Palabras clave: feminicidio; museo; colonialidad; modernidad; representación.

\begin{abstract}
:
This work establishes a relation between gender and representation in order to shed light over an epistemic gaze that tends to conceal the knowledge produced by women and override their role as knowing subjects. In this regard, the article analyzes, using the concept "coloniality of seeing", the representation made, through the exhibition "Femicide in Mexico" (2017) at the Memory and Tolerance Museum in Mexico City, of a group of activism women from the urban outskirts. This approach facilitates to observe how the curatorial use of a set of photographs triggered an epistemic injustice that excluded these women's voices from the knowledge/power field that was shaped by the exhibit. Thus, the article posits that collective recognition of women's lives, within the context of femicide violence, is sustain by the ways those lives are narrated and framed by women's actions and words. Key Words: femicide; museum; coloniality; modernity; representation.
\end{abstract}

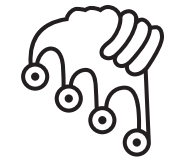

IZTAPALAPA

Agua sobre lajas 
E ste trabajo indaga sobre una mirada epistémica, de raigambre moderno-colonial, capaz de producir una in-visibilidad de la palabra/conocimiento de las mujeres y, por tanto, determinar la posición de prestigio que estas ocupan dentro de las relaciones sociales. A este respecto, la antropóloga Michelle Rosaldo asegura que el "lugar de la mujer en la vida social humana no es producto, en sentido directo, de las cosas que hace, sino del significado que adquieren sus actividades a través de la interacción social concreta" (1980ः 400). Así, para hablar en torno a lo que sugieren estas aseveraciones el presente artículo hace referencia a los performances emprendidos por el grupo de activismo, "Red Denuncia Feminicidios Estado de México", y la manera en que dichas acciones, encaminadas a visibilizar por medio del arte las violencias que padecen las niñas y mujeres en sus comunidades, fueron socializadas mediante algunas fotografías en la exposición, "Feminicidio en México", realizada en 2017 en el Museo de la Memoria y Tolerancia (de ahora en adelante se hará referencia a este como ммут) de la Ciudad de México. Analizar el uso de estas fotografías, dentro de la exhibición citada, servirá para elaborar una crítica sobre las formas en que dicha exposición construye una representación sobre las mujeres que luchan contra las violencias feminicidas en la periferia del Estado de México, inscrita en lo que más adelante se explicará, de la mano de Joaquín Barriendos, como una "colonialidad del ver" (20II). Es necesario aclarar que las fotografías recuperadas sobre los activismos mencionados, tanto en la exposición como en el catálogo que sirve de registro a esta, no tienen ningún texto y/o referencia que explique de dónde vienen esas imágenes. Simplemente fueron utilizadas como visualidades que ilustraban el discurso monográfico de la exposición, dejando a un lado los nombres, conocimientos, experiencias y memorias de estas mujeres (véase figura I).

En ese sentido, se valorará cómo una ética curatorial así deja a los colectivos de mujeres pobres simplemente como cuerpos sin voz, apareciendo ahí solo para "ilustrar" el discurso construido por la exposición. Se argumentará que dicho discurso, fincado en la herencia de una mirada moderno/colonial, termina por negar y al mismo tiempo se apropia de las memorias, experiencias e imágenes de las que 
se conciben en este caso como "otras", las mujeres pobres de la periferia urbana. Esta práctica museística estaría enmarcada por un babitus de la mirada del Estado-colonial (nacional) en América Latina el cual se define, según Rita Segato, a partir de su carácter "otrificador, alterofílico y alterofóbico simultáneamente" (2007ः 138). La idea de Segato servirá como punto de partida para argumentar cómo la figura del museo, en la modernidad, ha sido esencial para la construcción de un régimen de la mirada que se impone, simbólicamente, a través de "engullir" y "metabolizar" dentro de su campo escópico las formas de autorrepresentación de quienes considera las otras, los otros. Por ello, es necesario ubicar la figura del museo, en el contexto de la modernidad, como la construcción de un archivo cultural caracterizado, según Rolando Vázquez, por:

la apropiación, exhibición y desplazamiento de los mundos de vida de otras personas, animales y de la Tierra, transformando todos ellos en alteridad (...) el museo, al igual que la universidad, ha sido una institución central de la modernidad. Ha representado la diferencia colonial antropocéntrica, ha configurado el yo normativo y ha negado la alteridad a través de la exclusión y/o exhibición de la misma (Vázquez, 20r8: 49).



Figura I. Fotografía del performance, "Rostros de Fuego" (2016) organizado por la Red Denuncia Feminicidios y otros colectivos de mujeres del Estado de México. La imagen fue usada para ilustrar la sección "Tipologías del feminicidio" dentro del registro impreso de la exposición "Feminicidio en México" (2017). Imagen: José Ricardo Gutiérrez (2020). 
Desde esa perspectiva, emerge la genealogía colonial del museo como institución representativa de la modernidad, caracterizada, como bien lo ha señalado Walter Mignolo, por coleccionar y clasificar artefactos del mundo no europeo (2017). Este ha sido un conservacionismo signado por una preocupación que se construye alrededor de la explicación, jerarquización y ordenamiento de los objetos mismos, no de las memorias de los pueblos que los producen.

Para el caso que aborda este artículo vale la pena mencionar que la "otrificación" es una estrategia discursiva de la modernidad que ha derivado en una minorización política de las mujeres por medio de formas específicas de representación pública. El sentido que se construye en torno al pasado está marcado por una lógica narrativa que establece una serie de relatos y metáforas en torno a la masculinidad y feminidad que hacen eminente, como lo ha dicho Rita Felski en su trabajo, The Gender of Modernity, hablar de una "generización de la historia" y una "historicidad del género" que posibiliten comprender, por ejemplo, cómo la modernidad está definida por una narrativa mítica que hace que el hombre asuma el rol del sujeto colectivo de la historia, mientras que la mujer solo puede existir como otra, como el objeto, en lugar del sujeto de una narrativa histórica. La modernidad, según Felski, no solo se refiere a un conjunto de procesos sociohistóricos — colonialismo, capitalismo, burocracia, desarrollo tecnológico-, sino que también alude a una conciencia donde el género se revela como una metáfora central en la construcción del tiempo histórico (1995:9). Ante lo sugerido por Felski, se pueden abordar las formas sociales en que los mecanismos "otrificadores" de las mujeres tienen su registro en el reconocimiento histórico y cultural que invisibiliza las narrativas y los conocimientos producidos por ellas mismas. Vale la pena decir que ese reconocimiento se sustenta en un orden social que tiende a producir, mediante una hegemonía psíquica de género binaria, masculino/femenino, cierto tipo de percepciones culturales sobre los sujetos y los conocimientos y narrativas que generan.

En ese tenor se puede afirmar que la representación de las acciones de las mujeres de la periferia contra los feminicidios, llevada a cabo por el ммут, es una operación "otrificadora" que emerge a partir de lo que John Berger (20II) ha denominado "modos de ver", para apuntar cómo las prácticas sociales, deseos, técnicas y hábitos vinculados a un tiempo histórico afectan la forma en que vemos ciertas cosas, ciertas imágenes. En la última parte de este trabajo se escudriñará cómo el ммут construye una mirada sobre las mujeres del Estado de México que no puede entenderse al margen de un "modo de ver" hegemónico androcéntrico impuesto por la modernidad, donde se mira lo femenino como otredad, como reminiscencia política e histórica de la esfera pública. Así, la narrativa visual-espacial que elabora la exposi- 
ción "Feminicidio en México" (20I7) deviene en un dispositivo de disciplinamiento ocular-semiótico que organiza y jerarquiza el reconocimiento que se hace de las mujeres activistas; esas que han sido producidas como otras por medio de un "modo de ver" que define nuestro tiempo.

Sin embargo, lo importante aquí no solo es explicitar los mecanismos "otrificadores", a partir del uso de ciertas imágenes, mediante los que el ммут produce a las mujeres activistas de la periferia como una otredad que cobija, y a la vez desdeña por medio de la omisión de sus voces. También, como se argumentará más adelante, es necesario reparar en cómo esa operación asimilacionista/excluyente de la alteridad inaugura la posibilidad de afianzar un poder/saber sobre las formas en que se representa públicamente a las mujeres pobres en México por medio del "uso" que se hace de las experiencias, relatos y conocimientos generados por estas.

Se sostendrá así que estas mujeres de la Red son víctimas de una injusticia epistémica por parte de la mirada curatorial de la exposición "Feminicidio en México" (2017). Miranda Fricker en su obra, Epistemic Injustice: Power and the Ethics of Knowing, afirma que una injusticia epistémica (testimonial) se produce cuando la sujeta es agraviada en su capacidad como portadora de conocimiento. Esta injusticia niega el acceso a lo que originalmente nos dota de la condición de sujeto de conocimiento, aportando una carga simbólica que tiene como resultado que el hablante pasa a ser menos que un sujeto epistémico pleno (2017:235-236). Para el caso que aquí se retoma, se fundamentará que existe una asimilación invisibilizadora, por parte de la exposición, de las imágenes que registran los performances de la Red. Dicho uso de las imágenes termina por obstaculizar el reconocimiento y la interpretación de los conocimientos, experiencias y memorias de las activistas de la periferia mexiquense. La injusticia que estas mujeres sufren, siguiendo la idea de Fricker, termina por transmitir el mensaje de que no son adecuadas para aportar conocimiento, para ser sujetas de conocimiento. Este tipo de injusticia no puede entenderse como una injusticia de carácter jurídico, sino político, pues deriva de relaciones sociales de desigualdad y opresión que establecen formas de reconocimiento y clasificación de los sujetos y los saberes que producen. Las víctimas de las violencias feminicidas en México no solo son víctimas de un acto instrumental que les arrebata la vida o les genera alguna injuria; en sus cuerpos se escriben otras victimizaciones posmortem cuando el Estado, las universidades, los museos, las ong y la sociedad entera tienden a ubicar las memorias y los relatos de las mujeres víctimas en el campo de un sufrimiento esencializador, produciendo una imagen unívoca de la víctima enmudecida y rota por su dolor, pues como lo ha entendido bien Alan Badiou, en la espectacularización capitalista del sufrimiento de las víctimas, el cuerpo sufriente 
es separado de cualquier tipo de discurso: las posibilidades de su representación espectacular se potenciarían a costa de su palabra (2004), de sus conocimientos.

Establecidas las coordenadas analíticas que orientan la reflexión aquí expuesta, vale la pena hacer un breve señalamiento sobre el contenido de este trabajo. En la primera parte se ubica el contexto de las activistas de la Red, elaborando un brevísimo bosquejo sobre las violencias que padecen las mujeres en México. Dentro de este mismo apartado se describe el trabajo que han hecho las activistas de la Red por medio de los performances que organizan en el Estado de México. En la segunda sección se establece un marco teórico-metodológico que permitirá articular una lectura sobre las maneras en que se construye la mirada del ммут con respecto a las mujeres de la Red y sus activismos, a partir de lo que se explicará como "colonialidad del ver". En un tercer momento se propone un abordaje sobre el reconocimiento que se hace de los saberes producidos por las mujeres en la modernidad. Se sostendrá cómo esa tradición "impregna" y determina la manera en que se representa a las mujeres de la Red dentro del ммут. Finalmente, en la cuarta sección se desarrolla, a través de un vínculo entre imagen/texto/memoria, un análisis sobre cómo se construye y materializa la mirada museística que termina por invisibilizar los conocimientos producidos por las mujeres de la periferia mexicana, generando así una injusticia de carácter epistémico (testimonial).

\section{El contexto de la Red Denuncia Feminicidios Estado de México}

La visibilización de la tragedia feminicida en Ciudad Juárez, Chihuahua, a finales del siglo pasado, demostró que los cuerpos de las mujeres (pobres) en México son susceptibles de transformarse en los "bastidores o soportes donde se escribe la derrota moral del enemigo (...) los agredidos son cuerpos frágiles, no son cuerpos guerreros" (Segato, 20I6:6I). Ello se desencadenó, entre otras razones, a partir de la precarización económica neoliberal de las últimas décadas, aparejada con la intensificación de las violencias desatadas en los enfrentamientos entre grupos del crimen organizado y las fuerzas armadas del Estado mexicano desde hace poco más de 15 años. Esta situación ha definido la atmósfera bélica que ha cobrado la vida de cientos de mujeres (principalmente como víctimas de dichos conflictos), a través de maneras que se distinguen por el ejercicio de una crueldad que se escribe en sus cuerpos $y$ expresa un mensaje de dominación. Así, es necesario subrayar que la violencia contra las niñas y mujeres en México no solo se da en el ámbito íntimo, sino que alcanza y define la esfera pública convirtiendo el feminicidio en un crimen impersonal en el 
que la víctima no necesariamente guarda una relación con su victimario. De acuerdo con el "Mapa del Feminicidio" elaborado por la geofísica, María Salguero, tan solo entre el 16 de marzo y 30 de abril de 2020 se contabilizaron 405 casos de feminicidios de los cuales, según la autora, $63 \%$ fueron cometidos por el crimen organizado (Infobae, 2020). Y es en esta realidad nacional donde se enmarcan los activismos de mujeres de la periferia urbana en el municipio de Ecatepec, Estado de México, sobre los que aquí se habla.

Ecatepec es una gran mancha urbana que nació, según afirman Manuel Amador y Héctor Domínguez, en la periferia de la Ciudad de México como producto de las migraciones, durante los años ochenta y noventa, de pueblos originarios de los estados del centro del país que comenzaron a llegar a esta zona, como parte del proceso de desmantelamiento de la Reforma Agraria emprendido en los sexenios de Carlos Salinas y Ernesto Zedillo (Amador y Domínguez, 2012:26I). El municipio surgió como un espacio de abandono en el que se fraguó una precarización de la vida, que años más tarde se dejaría constatar a través de calles sin pavimentar, ausencia de alumbrado público, escuelas, centros de salud y de los nada alentadores números del Consejo Nacional de Evaluación de la Política de Desarrollo Social en México (Coneval), los cuales dan cuenta de que dicha demarcación encabezó la lista de los 15 municipios con mayor número de habitantes en condiciones de pobreza en 2015, con 786846 personas en esa situación (Fernández, 2018). Es este entorno precario en el que proliferan las violencias contra mujeres y niñas, tal como se confirma en las estadísticas del Observatorio Ciudadano Nacional del Feminicidio donde se establece que, entre 2014 y 20I7, ocurrieron 1420 asesinatos de mujeres en el Estado de México, siendo Ecatepec el municipio con más crímenes (Rojas, 2018).

Dichas violencias han sido la causa principal de las acciones llevadas a cabo por un grupo de mujeres y hombres llamado Red Denuncia Feminicidios Estado de México. La Red es un proyecto surgido en Ecatepec, cuyo enfoque social y político se encamina a evidenciar, desde el arte, las formas de violencia contra las mujeres. De ese modo, la Red ha funcionado como una plataforma para organizar acciones, presentadas como performance en distintos municipios del Estado de México, convocando principalmente a mujeres jóvenes y pobres. Es importante señalar que varias integrantes de la Red han sufrido en carne propia los efectos de las violencias feminicidas en sus comunidades.

Las jóvenes que conforman el colectivo de la Red han "puesto el cuerpo" durante varios años para llevar a cabo un reclamo que les permita ser miradas como vidas que importan, generando imágenes configuradoras de una discursividad que no solo tienen una dimensión simbólica, también sirven como una apertura política 
que facilita, como se verá más adelante, la construcción de un entorno narrativo sobre el cual la justicia emerge no como un decreto judicial, sino como una relación intersubjetiva y ética que deriva en la restitución de dignidad y valor a las palabras e historias de las mujeres pobres. Esta restitución será lo que alimente un sentido de comunidad, aludiendo a una relación tú-yo de encuentro, que sirve como base del vivir juntos/as.

La Red ha generado diversas acciones e intervenciones en espacios de la periferia urbana de la Zona Metropolitana del Valle de México, específicamente en sitios en los que se han encontrado cuerpos de mujeres y niñas asesinadas, con la finalidad de construir una memoria colectiva para esas víctimas de una "mala muerte" (véase figura 2). Desde 20II se han organizado más de 80 acciones y rituales de memoria para construir un duelo y luto colectivo por las asesinadas de la periferia. Una serie de "andanzas" para rememorar a esos cuerpos despojados de vida y dignidad. Estos ejercicios pueden ser pensados como un desacato al control y el silencio que impone la violencia criminal que domina el paisaje social de Ecatepec. De lo que se habla aquí es entonces de una práctica corporal, es decir, de acciones continuadas que nos permiten rastrear esas "grafías" (escrituras visuales), producidas por las mujeres pobres a partir de sus corporalidades, donde se manifiesta una desobediencia al orden impuesto por las violencias feminicidas y la precarización económica que viven dentro de sus colonias. Ello, no sólo representa un acto de resistencia contra la desigualdad y la opresión derivada del binarismo masculino/femenino. También es una forma de encontrar esperanza y hacerse un lugar propio en el mundo, en sus comunidades. 


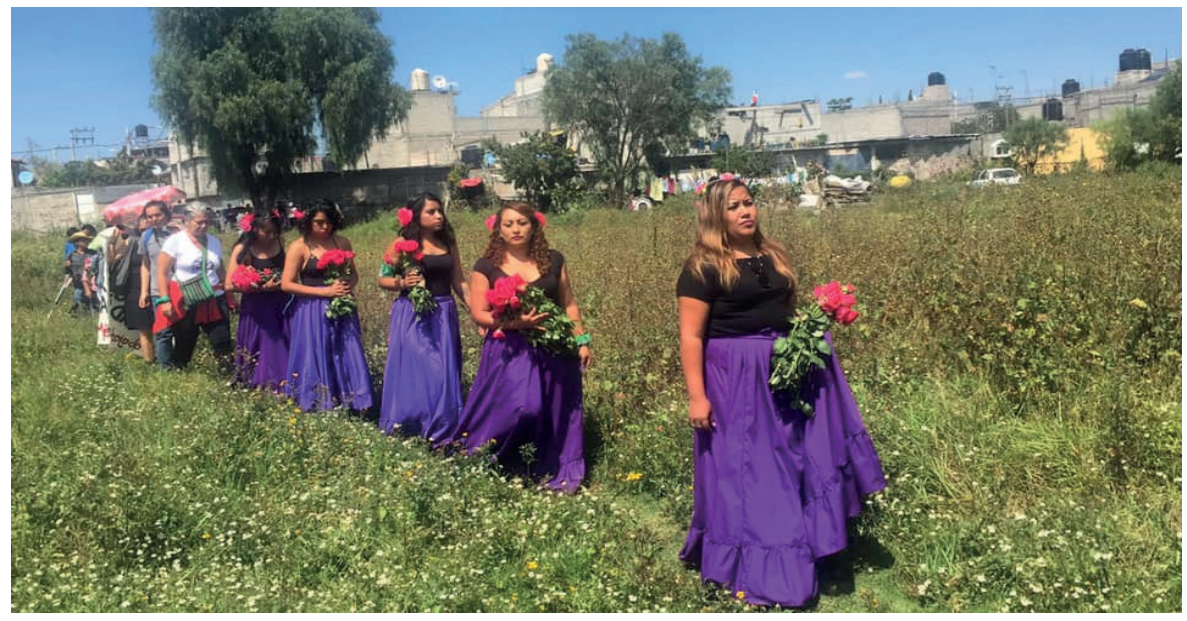

Figura 2. Performance "Mi triste despedida", realizado en 2019 en el municipio de Ecatepec como parte de la Primera Caravana contra los Feminicidios organizada por la Red, en un descampado donde fueron violadas sexualmente y asesinadas una mujer y su hija. Foto: Manuel Amador (2019).

\section{Una aproximación al problema desde la "colonialidad del ver"}

El problema planteado con respecto a las formas de representación que se hacen de las mujeres de la Red, dentro de la exposición "Feminicidio en México" (2017), se aborda desde la "colonialidad del ver", una categoría propuesta por Joaquín Barriendos. Según el autor, esta se refiere a la construcción de un régimen visual eurocéntrico, mercantil-capitalista y racializador que es constitutivo de la modernidad, remitiendo a formas de observación "antropófogas" de la alteridad, aparecidas en el siglo xvi y que persisten hasta ahora (20II). En este sentido, Barriendos ubica el origen de este régimen visual en el surgimiento de un saber proto-etnográfico, producido a partir de las experiencias y relatos de los colonizadores que intentaron dar cuenta, desde el ojo europeo de ese entonces, sobre la vida de los pueblos que consideraron parte de un "nuevo mundo". La constitución de estos saberes tejidos a partir del "evento americano" fomentaron, según el autor, "el encubrimiento de una sola episteme: la racionalidad eurocentrada y jerarquizada del sistema mundo moderno/colonial (...) el ego conquiro constituye el inconsciente óptico de la modernidad colonial" (Barriendos, 20II: 20). Desde esta perspectiva se configuró una manera de mirar capaz de invisibilizar otros regímenes escópicos alternativos a esta "colonialidad del 
ver". La anotación es importante, puesto que la manera en que percibimos el mundo y por tanto la producción y circulación de conocimiento depende del encuentro entre la percepción encarnada y la mirada, entendida esta última como aquello que le es externo al sujeto y emerge, como ya se ha dicho con Berger (2000) líneas arriba, del cruce entre hábitos, memorias, prácticas sociales, técnicas y deseos "incrustados" en un tiempo histórico que determinan la manera en la que se produce una visibilidad/ invisibilidad no tanto de orden empírico, sino político.

La noción propuesta por Barriendos permite pensar las maneras en que el museo, en el marco de la modernidad, es una estructura cuyas prácticas hacen posible rastrear los efectos de la "colonialidad del ver", tal como lo ilustra el caso de la exposición "Feminicidio en México" (2017), donde lo que expresa el discurso curatorial, a partir de una visibilidad/invisibilidad de las mujeres de la Red, se puede interpretar como un mecanismo que terminó por suprimir las voces de estas mujeres. Tomando en cuenta dichas conceptualizaciones, la estructura de este trabajo se construye con base en los siguientes principios fundamentales cualitativos: 1 . Elaborar algunos vínculos analíticos entre las formas en que se exhiben los relatos y modos de autorrepresentación de las activistas de la Red en la exposición "Feminicidio en México" (2017), y la invisibilización del conocimiento producido por las mujeres como un efecto de una tradición epistémica de la modernidad/colonial; 2. Entender la figura del ммут с como una institución, definida por una "colonialidad del ver", que termina por producir una mirada asimiladora $y$, a la vez, excluyente de los conocimientos generados por las mujeres de la Red; 3. Analizar bajo una relación imagen/texto/ memoria las fotografías de los activismos de la Red, usadas en la exposición mencionada, como una representación que convierte a las mujeres de la periferia en mero objeto contemplativo sin ninguna voz.

\section{La invisibilización de los saberes de las mujeres (pobres)}

Los caminos analíticos bajo los que se plantea abordar los modos de representación de las activistas de la Red en la exposición "Feminicidio en México" (2017) también pueden dar luz sobre la exclusión epistemológica de las mujeres, en general, como sujetas productoras de conocimiento o cuando son invisibilizadas por los sistemas epistemológicos dominantes de corte moderno/colonial. De ese modo, debe entenderse que en las formas de representación y circulación del conocimiento también existe una disputa que es política. Lo político se conceptualiza aquí en el sentido propuesto por Jacques Rancière: no es una circunstancia del Estado y mucho menos 
de un sistema económico o ideológico. Es una relación de subjetivación que define lo visto y lo invisto, los que cuentan y los que no cuentan dentro de un marco social: "la democracia no es ni una forma de gobierno ni un estilo social, es el modo de subjetivación por el cual existen sujetos políticos" (Rancière, 2007:9). Las formas de representación son políticas no solo porque organizan y jerarquizan las maneras en que se reconoce y aprehende a los sujetos, sino porque también ordenan y legitiman los conocimientos que llegan a producir.

En ese sentido, las maneras de representación de las integrantes de la Red en el ммут у la visibilidad/invisibilidad de sus acciones que ahí emerge constituyen un problema epistémico vinculado con las formas de saber y la producción de conocimiento de estas mujeres en torno a las violencias femincidas en México, pues en los relatos/memorias que derivan de sus performances reside un "conocimiento situado" sobre la situación de las mujeres en la periferia urbana. Donna Haraway (2003) afirma que el conocimiento se construye siempre de acuerdo con las circunstancias específicas y contigentes que atraviesan a los sujetos. Por esa razón, las experiencias y memorias generadas en los activismos de estas mujeres son el núcleo generador de un conocimiento situado en torno a la relación género-neoliberalismo-violencia feminicida-periferia en México. Ellas transmiten conocimiento mediante su testimonio, sus memorias. En ese mismo tenor, Mondragón y Amador al referirse a estos ejercicios performativos de la Red han dicho que las acciones son una propuesta para que las mujeres que participan se vuelvan investigadoras de su propia realidad, pues el énfasis de estos performances "no está puesto en certificar el dominio de determinada metodología, sino en desarrollar capacidades para pensar la propia vida de manera radical" (Mondragón y Amador, 2020: 37).

El reconocimiento y la escucha de las voces/experiencias de las mujeres, en general, y los conocimientos que de ahí surgen están determinados por las maneras en que las mujeres han sido concebidas como sujetos políticos dentro de las democracias liberales, pues a pesar de ser reconocidas como ciudadanas, sigue prevaleciendo, como ha dicho Carole Pateman, una creencia que las piensa como "no aptas" para la vida política, es decir, una especie de "desorden de las mujeres", el cual, según Pateman, solo se constituye como un problema social y político en la modernidad (1980). Este "desorden" se sostiene a partir de la oposición binaria que elabora la modernidad entre natrualeza versus cultura, produciendo una serie de relaciones sociales sexistas en las que las mujeres son vinculadas con la naturaleza, pero también con la emoción, la irracionalidad y la indisciplina. Ello ha desencadenado una forma de mirar el conocimiento que producen a partir, como indica Guillermo Núñez, de una desvalorización de sus actividades cognitivas (2004). En esa misma línea, Rita 
Felski asevera que el género no solo afecta el contenido del conocimiento histórico que acumula la humanidad (incluyendo o dejando fuera ciertos conocimientos), sino que también tiene un impacto en las asunciones filosóficas que determinan nuestras interpretaciones de la naturaleza y los procesos sociales (1995).

Las concepciones descritas anteriormente han configurado sistemas de conocimiento androcéntricos sobre los que se finca la ciencia moderna. Es por eso que hay que estar dispuestos, como lo ha señalado Sandra Harding, a tratar de "contemplar estructuras y prácticas intelectuales de la ciencia como artefactos culturales, en vez de como mandamientos sagrados entregados a la humanidad con la ciencia moderna" (1996:36). Las aseveraciones de Harding invitan a pensar cómo el género no solo ha dejado una huella en la ciencia y sus métodos, sino que la modernidad ha consturido una mirada que ha desatado una injusticia epistémica donde las mujeres son forcluidas como sujetos cognoscentes.

En este trabajo se piensan y se entienden las experiencias derivadas de los performances llevados a cabo por mujeres sobre las que aquí se habla, como la materia prima de un conocimiento que se genera en la intiución de una mirada, sobre la marcha. En el contacto y encuentro entre los cuerpos y su gesto. Por esa razón, este es un conocimiento que no solo es desvalorizado a partir de su firma femenina, sino que también es degradado por el ojo moderno cientificista que rechaza, como dice Emmanuel Levinas:

todo aquello que hay de inmediato, de concreto e irreductible en la percepción directa. Porque el mundo de la percepción se ofrece como relativo, porque remite a una realidad que estaría detrás del mismo, la percepción carece para el naturalismo de valor científico y no sirve más que de punto de partida para un razonamiento que tendrá que construir el mundo real dando cuenta de las apariencias que se ofrecen como carentes de estabilidad y fundamento (2004:43).

La crítica de Levinas al naturalismo enarbolado por la modernidad hace pensar la manera en que a partir de la intuición que se fabrica en el acto de percibir se produce una forma de conocer la realidad. Por eso, el acercamiento que tienen las mujeres de la Red con una realidad violenta, a través de convertir sus cuerpos en imágenes por medio del performance, las hace mirar y sentir su propio entorno de una forma determinada, produciendo un conocimiento guiado por la intución y la impredecibilidad que define sus acciones. Tener presente esto ayudará a dar una posible explicación a la supresión que hace el ммут de los relatos de las mujeres de la Red: la percepción de estas mujeres sobre sí mismas y su relación con sus entornos 
es invisiblizada, pues los conocimientos que producen no son considerados, desde la "colonialidad del ver" que define la mirada curatorial de la exposición, como algo "útil" o que valga la pena mencionar dentro de la expo, puesto que son conocimientos generados en la intuición que resuena en el cuerpo y, por tanto, quedarían fuera del paradigma epistémico hegemónico de la modernidad, fundamentado en la producción de conocimiento desde un ámbito incorpóreo. Lo que queda, entonces, es una operación asimilacionista donde el ммут, por medio de la figura de la curadora de la exposición "Feminicidio en México" (2017), considera y clasifica como "útiles" las imágenes que las activistas del Estado de México han producido con sus cuerpos, no para darles una presencia interpeladora dentro de la exposición, donde su voz pudo haber sido registrada y compartida a los visitantes del museo, sino para conformar y satisfacer los criterios de una propuesta estética determinada que termina por adaptar dichas representaciones visuales como objetos que "ilustran" las paredes de la exhibición y las páginas del catálogo que la registra. Este ejericio de silenciamiento de las voces, experiencias y conocimientos de las mujeres activistas de la periferia se convierte en un mecanismo que produce eso que Ramón Grosfoguel, aludiendo a la canadiense Liam Betasamosake, define como "extractivismo epistémico", el cual refiere la explotación neoliberal desmedida y por despojo de los recursos naturales y cómo esa misma actitud se traslada al dominio del conocimiento: busca extraer ideas para colonizarlas por medio de subsumirlas al interior de los parámetros de la cultura y episteme occidental (Grosfoguel, 2013). Así, es necesario decir que dicha subsunción ocurre mediante el espíritu clasificador de la modernidad que determina una "utilidad" o una "inutilidad" de ciertas ideas y/o conocimientos. Quizá la tarea por hacer no es tanto que los conocimientos producidos por las mujeres sean vistos como "útiles", sino que su valor se construya fuera de los parámetros de ese enfoque epistemológico naturalista, androcentrado y moderno que hace visible o invisible; útil o inútil un conocimiento.

\section{La mirada construida por la exposición "Feminicidio en México"}

La exposición "Feminicidio en México" (20I7) se puede abordar desde varias aristas. La más obvia vincula el carácter informativo y monográfico de la exhibición con la intención de generar una conciencia social sobre la exclusión y violencia que viven las mujeres en México. Así, el visitante lo primero que encontraba al entrar era la definición del término "feminicidio". En salas posteriores también se podían mirar y leer estadísticas, tablas, recomendaciones, testimonios de las víctimas e instala- 
ciones hechas por mujeres artistas que refieren el problema que atraviesa México en este sentido. De hecho, dentro del registro impreso que sirve de memoria a la exposición, Linda Atach Zaga, su curadora, destaca la relevancia y el propósito de su trabajo con las siguientes aseveraciones: "es un homenaje a las víctimas del feminicidio, pero también una fuente de prevención para jóvenes de ambos sexos, el clamor de una sociedad que pide 'ni una más'. Un urgente llamado a la acción y a la conciencia" (Atach, 2017: 2). En esas mismas páginas se lee lo siguiente bajo la firma de Ana Guezmes, representante en México-onu mujeres: "buscamos implicar a hombres y a niños como defensores de la igualdad de género (...) las leyes son un paso, pero requerimos un profundo cambio cultural (...) Nuestro llamado es a unir mujeres en un horizonte común por la igualdad de género" (Atach, 2017:3). Finalmente, las palabras introductorias son cerradas por el Instituto Nacional de las Mujeres (INMUjeres) del gobierno mexicano: "desde el Instituto se defendió como una prioridad impulsar $\mathrm{y}$ acelerar las acciones para prevenir, sancionar $\mathrm{y}$ erradicar la violencia contra las mujeres" (Atach, 2017:5).

Las aseveraciones anteriores sirven para establecer propósitos loables que animan el discurso curatorial de la exposición en nombre de la "igualdad de género". Sin embargo, este conjunto de enunciaciones no puede leerse al margen de lo que se concibe como "igualdad de género" en el marco de la modernidad, lo cual se explica, según Anne Phillips, en la manera en que el curso histórico y social de la modernidad estableció la igualdad como ideal, pero las condiciones de este pensamiento estuvieron a la vez marcadas, paradójicamente, por el afianzamiento del colonialismo y la naturalización del género y la raza como categorías de dominación. En ese mismo tenor, Phillips asegura que la "igualdad" como un ideal inherentemente moderno apela más a lo cognitivo que a lo político:

la 'igualdad', desde el ojo de la modernidad, es algo fundamentado o justificado por atributos acerca de los sujetos (como cuando decimos todos los humanos tienen una cualidad ' $x$ ', por lo tanto deben ser tratados como iguales), cuando en realidad, debería ser pensada como algo que se realiza y se reclama (Phillips, 2018: 850).

Tomando en consideración las reflexiones planteadas se puede decir que las palabras de la curadora y de las representantes de ONU-Mujeres e INMUJEREs apuntan hacia una concepción de "igualdad de género" que, como sugiere Phillips, se yuxtapone a un espíritu moderno que es ordenador y jerarquizador de los cuerpos y sus saberes. Todo esto se constata, como ya se adelantó, en las formas de representación que establece la exposición en torno a los activismos de las mujeres de la Red: por un 
lado, se usan fotografías en las que se muestra el trabajo que llevan haciendo por años para construir una voz colectiva contra las violencias que padecen; por el otro, ese mismo uso de las imágenes termina por ocultar sus voces, sus memorias. Ahí, en estas fotografías expuestas en las paredes del museo, en las que se muestra y a la vez se oculta a las mujeres de la periferia, es donde toma forma una mirada, un "modo de ver" que jerarquiza y enmarca de una manera concreta las experiencias de las integrantes de la Red. Esta tensión entre visibilidad e invisibilidad de las activistas convertiría dichas fotografías en lo que el mismo Barriendos ha denominado como "imagen-archivo". Una categoría que hace referencia a la "función de ciertas imágenes formadas por múltiples representaciones, sedimentadas unas sobre otras, a partir de las cuales se conforma una cierta unidad hermenéutica y una unidad icónico-arqueológica" (Barriendos 2008:10). Así, las imágenes usadas dentro de la exposición construyen una representación de la acción colectiva de las mujeres pobres de la periferia urbana ante las violencias feminicidas que sufren, mezclada con sedimentaciones de significados de nulidad de su palabra y experiencia, los cuales emergen no solo por la ausencia de cualquier referencia que haga saber quiénes son esas mujeres, sino que se vinculan a una cultura visual contemporánea masificada en la que se ha concebido lo femenino como ornamento y otredad.

Por las razones recién esgrimidas, se propone entender la figura del ммут, bаjo el marco de la modernidad, como una institución reproductora de un poder (clasificador, asimilador y excluyente) a partir del cual se organizan y se representan una serie de saberes para sus audiencias. Con respecto a esta proximidad entre poder $y$ saber, Michel Foucault notó que ambos elementos

se implican directamente el uno al otro; no existe relación de poder sin constitución correlativa de un campo de saber, ni de saber que no suponga y no constituya al mismo tiempo relaciones de poder (...) los procesos y las luchas que atraviesan y constituyen el campo de saber/poder son las que determinan las formas y los dominios posibles del conocimiento (Foucault, 2009: 37).

El ммут, por medio de la exhibición y el ejercicio curatorial que esta implica (selección, jerarquización y organización de los contenidos), se convierte en un dispositivo de saber/poder capaz de construir una representación sobre las mujeres activistas del Estado de México. Este museo encarna así el espíritu ordenador de la episteme clásica europea del siglo xviı, la cual, según vuelve a decir Foucault, está definida por "la puesta en orden por medio de signos que constituye todos los saberes empíricos como saberes de la identidad y la diferencia" (2006: 64). A partir de esto, se pone de 


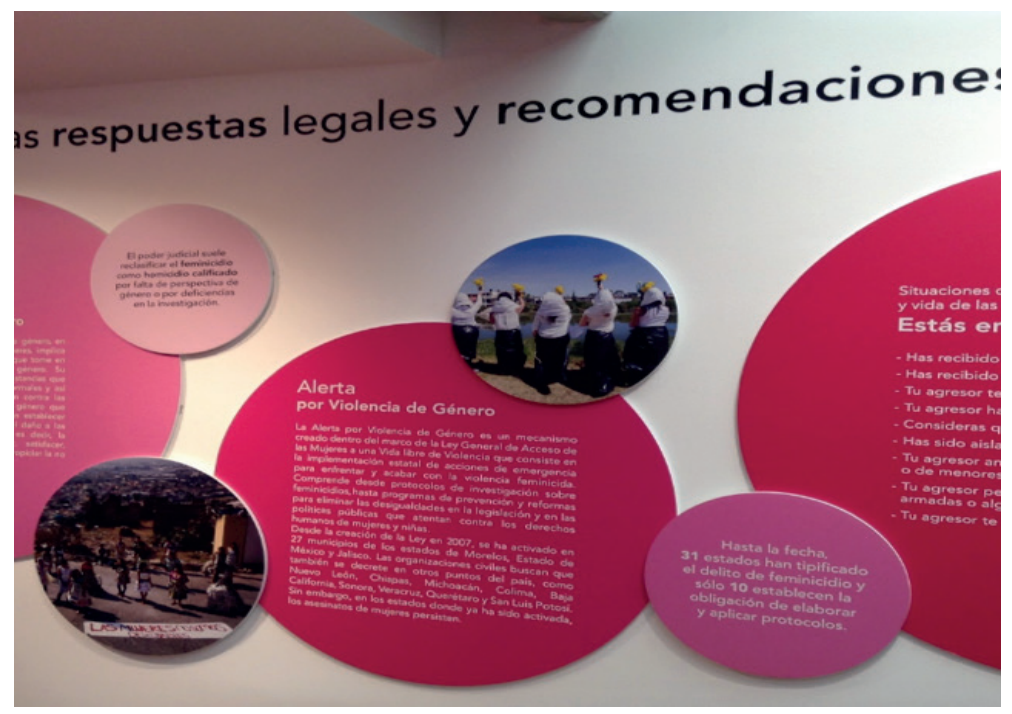

Figura 3. Exposición “Feminicidio en México”. Museo Memoria y Tolerancia. Foto* José Ricardo Gutiérrez (2017)

relieve la importancia de establecer el vínculo entre la representación y las relaciones de saber/poder, pues es en este nexo donde se revela o se oculta, se valida o se deslegitima una voz. La representación, en este caso, no puede ser conceptualizada de otra manera que no sea la de una lucha estético/política, pues en las maneras de representar se constituyen las formas ordenadoras de distinción y desigualdad social que distribuyen valor y reconocimiento entre los sujetos y sus saberes.

De ese modo, el objetivo dentro de este apartado se centra en analizar el tratamiento que hizo la exposición "Feminicidio en México" (20I7) de las fotografías que registran los activismos de la Red, bajo una relación imagen/texto/memoria que posibilite entender que dichas imágenes no pueden simplemente concebirse como objetos que al exponerse ilustran y tematizan las violencias contra las mujeres en México; en cambio, deben interpretarse como el producto de un montaje en el que se da un cierto "uso" de las fotografías, produciendo una visibilidad/invisibilidad que emerge como el índice de ese campo de "saber/poder" configurado por la mirada curatorial de la exhibición discutida. Tanto en el libro impreso, que puede conseguirse en la tienda del ммут, como en la exposición montada, algunas de las fotografías que se usaron, como ya se anticipó, solo estaban ahí para ilustrar los 
textos que se exhibían. Varias de las fotografías que se exponían en las paredes de este museo (véanse figuras 2, 3 y 4) solo servían de apéndices visuales de los tópicos que intentaba abordar la exposición de manera escrita: "Tipologías del feminicidio", "Respuestas legales", "Recomendaciones", "Alerta por violencia de género", etcétera. Lo mismo sucedió con el uso de las imágenes dentro del libro que sirve de registro a la exposición (véanse figuras 6 y 7). Esto más que ayudar a la visibilización de las activistas de la Red, considerando sus voces, memorias y experiencias, solo contribuiría a su ocultamiento y, por tanto, afectaría el reconocimiento de estas mujeres como sujetos cognoscentes de su propia realidad.

Suprimir las voces de las activistas de la Red y solo mostrar las fotografías que registran sus acciones puede interpretarse como un gesto que se inscribe en la tradición de la "colonialidad del ver", pues las experiencias y los relatos de estas mujeres son asimilados por los parámetros curatoriales que responden, en este caso, al "uso" de la imagen como elemento ilustrativo de otro discurso que no da cuenta sobre lo que la imagen dice. En ese sentido, lo que aquí se discute tiene que ver con lo que teje la mirada curatorial desde la elección y el montaje de las fotografías sin ninguna referencia a las mujeres que ahí salen, más que el nombre de su autor, el fotógrafo Iván Casteneira. En la elección y el montaje se expresa algo a través del "uso" que se da a las fotografías expuestas. El ммут "usa" los discursos producidos por las integrantes de la Red Denuncia para los fines del guion curatorial de la exposición, lo cual termina por construir una mirada sobre ellas. El "uso", ha dicho Sarah Ahmed, es una técnica para configurar mundos y cuerpos (2019: 12). En el "uso" curatorial de los relatos de las mujeres pobres para exhibirlos en las paredes del ммут, siguiendo esta idea de Ahmed, se contribuye a configurar un mundo en el que se miran de una forma particular los cuerpos y las vidas de las mujeres de la periferia.

Entonces, lo que debe pensarse es lo que el "uso" de estos materiales expresa, pues es en ese "uso" en el que se hace distinguible la invisibilidad que cancela las voces de las mujeres que viven en la periferia. En este "uso" se delata la "colonialidad del ver" ejercida sobre las narraciones de estas mujeres, ya que los conocimientos emanados de sus relatos/voces son suprimidos por la mirada ordenadora y jerarquizadora que guía el ejercicio curatorial. Dicho "uso" de las fotos dejaría sin respuesta algunas preguntas para los espectadores de la exposición que no conocieran el trabajo de la Red: ¿Quiénes eran esas jóvenes a la orilla de un canal de aguas negras cargando flores (véanse figuras 4 y 6 ) o las que portaban vestidos de basura (véanse figuras 5 y 7 )? 

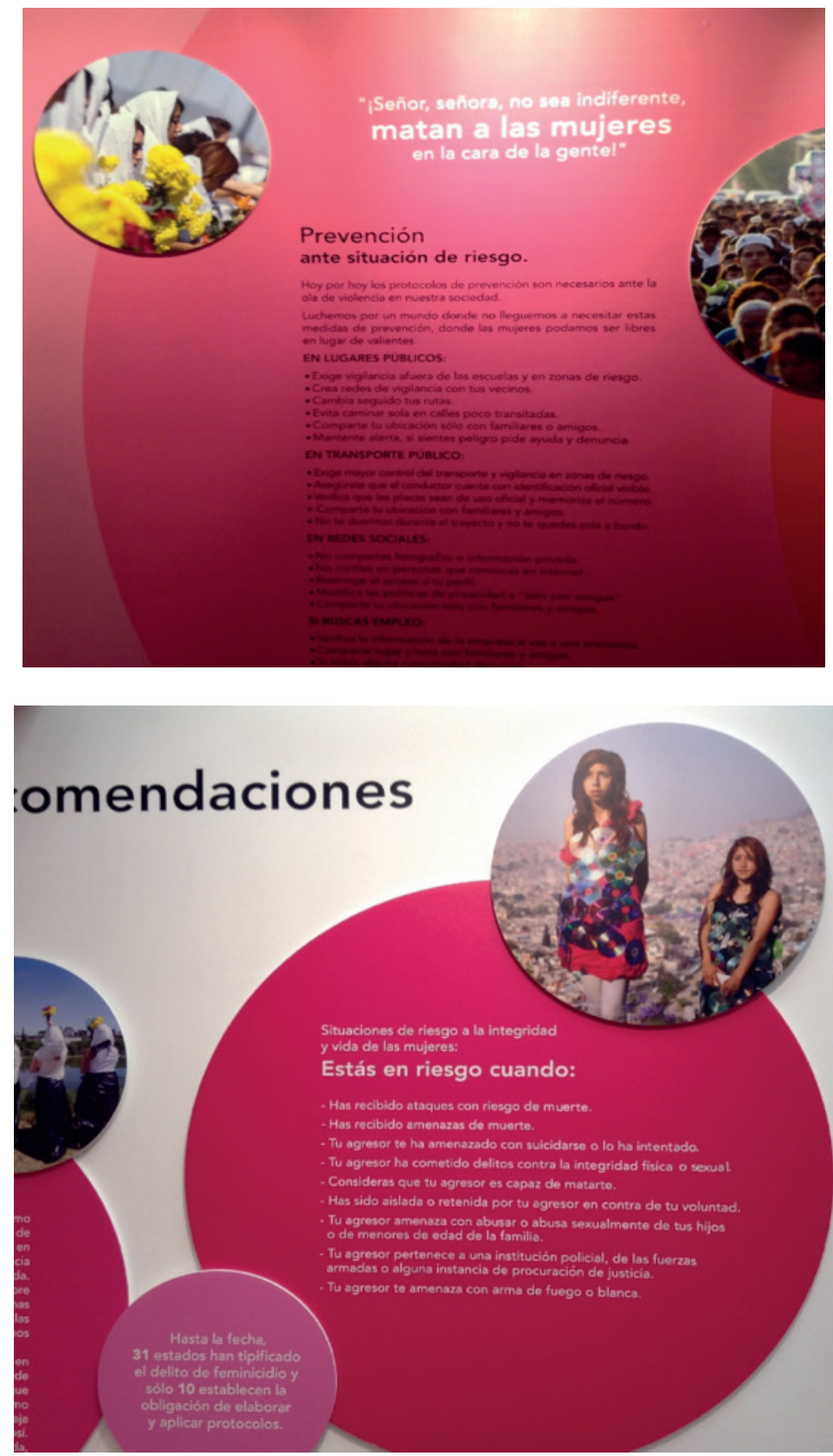

Figuras 4 y 5. Exposición "Feminicidio en México". Museo Memoria y Tolerancia. Fotos: José Ricardo Gutiérrez (2017) 

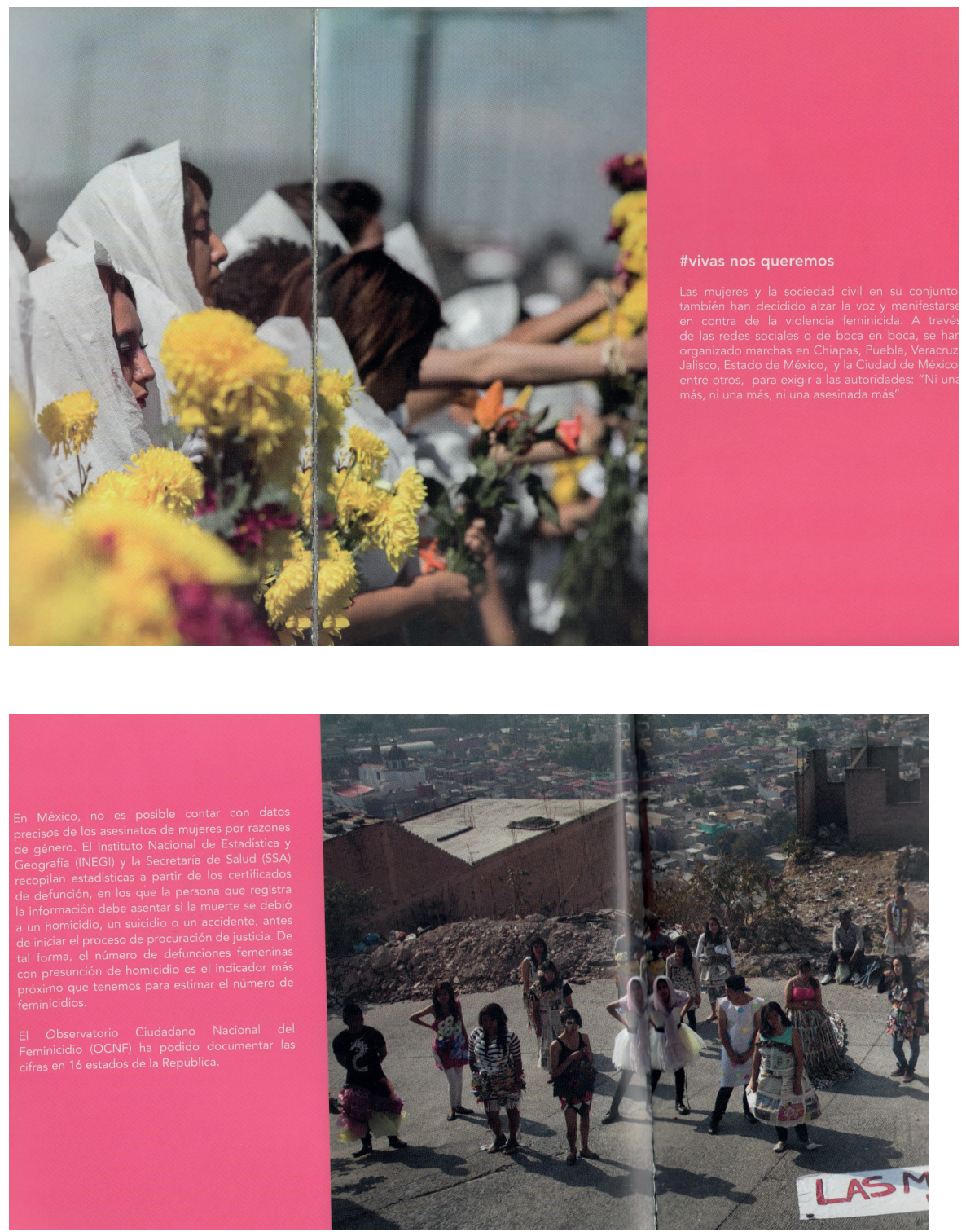

Figura 6 y 7. Fotografías de los performances,"Los feminicidios en Río de los Remedios" (2015) (arriba) y "Las mujeres de la periferia no somos desechables" (2015) (abajo) organizados por la Red Denuncia Feminicidios. Las imágenes fueron usadas para ilustrar el contenido escrito del registro impreso de la exposición "Feminicidio en México" (2017). Imágenes: José Ricardo Gutiérrez (2020). 
¿Cómo es que esas mujeres llegaron ahí? ¿Cómo es que ellas se han organizado para realizar dichas acciones? ¿Por qué el único nombre que aparece al hacer referencia a las fotografías mencionadas es el de su autor, Iván Casteneira? Ante todas estas preguntas surgirían otras más, que son consecuencia de las anteriores: ¿Cómo puede esta exposición tomarse como "un homenaje a las víctimas", en palabras de su curadora, cuando ni siquiera se reconocen los nombres y el trabajo de las mujeres que los espectadores miran en las paredes del museo? ¿Por qué se ponderan (bajo qué criterios) como objeto de exposición las fotografías por encima de los performances y las voces de las activistas?

Al lanzar estas preguntas se podría objetar su relevancia a partir de decir que las fotografías en cuestión son de un autor, y la exposición es diseñada por la curadora. En ese sentido, el objeto que interesa exponer son las fotografías, no los performances de la Red. Sin embargo, aceptar esta postura es un camino para evadir el hecho de que el objeto que se expone (la foto) se constituye y define como tal a partir de cómo se "usa" dentro del montaje de la exposición. Es el montaje, producto de una mirada ordenadora, el que hace aparecer de una u otra manera las fotografías. El montaje del objeto también expresa algo a partir del "uso" que se le da al segundo dentro del primero. Lo que se está discutiendo no es tanto la foto como objeto de la exposición o como una imagen que posibilita la aparición sensible de las activistas, sino la manera en que el objeto es "usado" dentro del discurso curatorial, y, por tanto, lo que ese "uso" expresa y tiene como efecto: la (in)visibilidad de las mujeres de la periferia, a partir de la supresión de sus voces y experiencias en la Red.

Siguiendo la línea anterior, se puede afirmar a partir de lo que expresa el "uso" de las fotografías discutidas, que las intenciones de la narrativa curatorial se centraron en articular un discurso cuyas voces eran las de las expertas, las académicas y las artistas. Las mujeres pobres solo se presentaron ahí, por medio de fotografías, para ilustrar un contenido "experto" y "autorizado". Su palabra una vez más fue borrada, ya no por obra de la ineptitud de la policía o de cualquier burócrata, sino por la mano de un museo, paradójicamente llamado de la "Memoria y Tolerancia", que a través de los criterios de una curadora decidió presentar estas fotografías como acciones aisladas, inconexas y, a su vez, articuladas bajo la sombra del discurso monográfico de la exposición. Es claro, como ya se mencionó, que el propósito de mostrar estas imágenes no era recuperar las experiencias de las activistas, sino "usar" las imágenes que estas han producido como el componente que suplementa lo dicho por la "autoridad" (museo, curadora, onU, inmujeres). Esta situación nos lleva a un señalamiento importante en torno a las maneras en que las representaciones de las activistas de la Red exigirían un acompañamiento de las voces de estas, de su palabra, 
aunque sea de manera diferida. Para que las mujeres de la Red puedan aparecer ante la mirada no solo es necesaria su representación figural en las paredes del museo o en el catálogo de la exposición, sino que es menester cederles esos espacios de enunciación para que puedan hablar con su propia voz. Y es en este sentido que el "espacio de aparición", como dice Julia Kristeva, guiada por Hannah Arendt, es

en potencia un espacio político de acción e interlocución plurales (...) el espacio de aparición de la polis es tal que le exige a cada uno que demuestre un "coraje original" que consiste en "actuar y hablar", abandonar el abrigo privado para exponerse a los otros y, con ellos, estar dispuesto a correr el riesgo de la revelación. Esa sería la primera condición de la política de la revelación; manifestar quién soy y no lo que soy (...) el qué se reduce a las apariciones sociales y a los atributos biológicos. Aunque las cualidades, los dones, los talentos, los defectos pueden singularizar al individuo, esas particularidades remiten a un qué, espécimen, que se pierde en el anonimato de la especie (una vida biológica de la que el ser humano debe extraerse para concretar su especificidad). El quién sería precisamente ese desgarramiento, ese daimón de los griegos que aparece tan nítidamente, tan claramente a los otros, pero que sigue oculto para la propia persona (Arendt, 2013: 85, 164).

Bajo estas ideas es necesario aclarar que solo en la posibilidad de narrar es que se delinea el quién. En pocas palabras, es entender que la existencia del ser y su aparición subyace en el relato; el poder de la palabra narrada es lo que le daría al sujeto la oportunidad de aparecer ante la mirada ajena, configurando, nos recuerda Kristeva, lo que la misma Arendt llamó el inter-esse, ese mundo que se entreteje del "entre-dos" y que como "modelo político no se basa por lo tanto en nada más que en la acción y la palabra, pero nunca una sin la otra” (2013: 77). Estas anotaciones son importantes para el caso que aquí analiza, puesto que la supresión de la palabra de las activistas de la Red es un mecanismo que no solo suprime el quién, sino también el "entre-dos" como un espacio, en el que a partir del encuentro adquieren forma el testimonio y la memoria. Lo que suprime la exposición "Feminicidio en México" (2017), para el caso de las mujeres de la periferia, es la posibilidad de enunciar las memorias que han fabricado y el conocimiento que en estas habita. En esta operación se consumaría la mirada colonizadora del museo, que transforma el quién en un qué $y$, a la vez, convierte la memoria en una lucha que impacta en nuestras formas de producir conocimiento sobre el presente y el futuro. Para poder elaborar cualquier previsión sobre lo que viene es necesario mirar el presente, pero sobre todo el pasado que lo antecede. La rememoración sería entonces conocer los fragmentos del por- 
venir. Reconocer la valía epistémica que se condensa en las memorias narradas por las mujeres que han sufrido las violencias feminicidas sería una manera con la que contamos para elaborar una visión sobre un futuro no feminicida.

Las fotografías de la exposición, que hablan de las acciones de la Red, para que realmente lleguen a interpelarnos necesitan una voz que guíe nuestra mirada y la contextualice en la pobreza que prevalece en los municipios donde estas jóvenes viven. Con ello no se afirma que la imagen por sí misma no tenga un potencial comunicativo, que en este caso alude a las fotografías de las activistas como una manera visual que registra la metaforización de la situación violenta que viven las mujeres en el Estado de México; sin embargo, al presentarse las fotografías desprovistas de cualquier contexto, las quiénes se difuminan. Por eso, articular imagen y texto no sería para ilustrar uno con el otro, como lo ha hecho la exhibición "Feminicidio en México" (2017), sino para entretejer relatos y lenguajes que son paralelos, pues sería en ese binomio entre voz y mirada donde fraguarían los indicios de una vida, de un quién; una existencia que sufre en carne propia las vejaciones y humillaciones de su familia y su comunidad. De otra manera será imposible captar la pertinencia y relevancia estético/política de aquellas fotografías. $\mathrm{Al}$ no existir ningún texto o algo similar que permita enterarnos sobre quiénes son aquellas adolescentes y por qué están paradas con vestidos hechos de basura, teniendo como telón de fondo la pobreza de sus comunidades (véanse figura 5 y 7), se dificultaría la valoración y el reconocimiento, por parte de las audiencias que visitan la exhibición, de las maneras en que las vidas de estas mujeres se encuentran sometidas a la violencia feminicida que predomina en su municipio y en todo México. La narración de las acciones de la Red originada en el encuentro entre imagen y palabra no aludiría simplemente a un conjunto de acciones que se relatan desde una perspectiva, sino que sería más bien una narración actuante, un relato otro que ocuparía al museo momentáneamente para participar de otra política, la política de la memoria compartida.

Estas fotografías necesitarían las palabras, aunque fueran diferidas, de quienes ponen el cuerpo contra las violencias feminicidas en la periferia del Estado de México. Ellas son mujeres con nombre y apellido que en las paredes del museo solo aparecen como figuración plástica y no como sujetas. Quizá, en contraste, lo que sí se pondera muy bien dentro de esta exposición son las experiencias de las reconocidas artistas Mayra Martell y Teresa Margolles, quienes son autoras de dos instalaciones dentro de la exhibición: "Cuartos Vacíos" (2017) y "Pesquisas" (2017), respectivamente. No solo porque tenemos sus nombres y apellidos. También porque en la exposición y en el libro que deriva de esta se registran los procesos, motivaciones 
y experiencias que rodearon la creación de sus obras. Por ejemplo, Martell explica su obra "Cuartos Vacíos" (2017) como sigue:

Hasta el momento, sigo documentando todo lo que se produce en torno a la desaparición de mujeres de Ciudad Juárez. El lugar se ha convertido en un mapa personal, trazado de posibles trayectos de todas ellas. Las imagino caminando por ahí: no dejo de buscar en las personas rasgos o rostros de algunas de las jóvenes que no han podido volver a sus casas. Siempre pienso donde podrán estar (Martell, 2017: 39).

Se puede afirmar que lo que la exposición discutida elabora es una tematización del problema de los feminicidios en México, sin embargo, para contribuir a hacer justicia a las mujeres necesitamos ir más allá de una tematización y, en cambio, ir descubriendo formas de intervención (respuesta), que solo serán alumbradas en la medida en que antepongamos el quiénes sufren al qué sufren. Para abrir una alternativa de justicia, dice Estela Fernández, "es necesario contar con el resurgimiento y fortalecimiento del sujeto-el sujeto aplastado, reprimido, pero que, a pesar de todo resiste y todavía grita" (2012: 24). Entonces nos daremos cuenta de que lo hecho por el ммут a través de la curadora y el resto de personas que participaron en el montaje de la exposición citada ha sido dificultar el aparecimiento, ante la mirada de sus audiencias, de las sujetas oprimidas. El grito de las mujeres de la periferia ha quedado silenciado una vez más; sin embargo, ellas seguirán ahí gritando lo más fuerte posible.

Todo esto se sostiene a pesar de que en la misma exposición Irinea Buendía, madre de Mariana Lima Buendía, quien fue asesinada por su marido en 2010 en el Estado de México, sí goza de un espacio en el que se cuenta su historia como víctima. De hecho, la fotografía y la palabra de Irinea cierran el libro que sirve de registro a la exhibición, además de ocupar un lugar que era espacialmente preponderante dentro de la sala del museo (véase figura 8). En el contexto mexicano, nombres como el de Irinea Buendía gozan de una notable visibilidad en la lucha contra los feminicidios. ${ }^{1}$ Su presencia dentro de esta exhibición debe tomarse como una his-

1 Irinea Buendía fue reconocida en 2018 con el Premio Nacional de Derechos Humanos, Don Sergio Méndez Arceo, en su xxvi edición, debido a las contribuciones que ha hecho a la promoción y defensa de los derechos humanos de las mujeres. El activismo de Irinea comenzó cuando el 28 de junio de 2010 su hija Mariana Lima Buendía fue asesinada por su esposo, Julio César Ballinas, en el municipio de Ciudad Neza, Estado de México. Asimismo, es importante decir que gracias a su lucha, Irinea logró señalar las irregularidades en la investigación realizada por autoridades del Estado de México. 
toria emblemática de la lucha contra las violencias feminicidas; sin embargo, ello no quiere decir que en ese caso se aglutine toda la realidad y complejidad del problema. Existen otras voces oprimidas que sería necesario escuchar y hacerles un lugar en los espacios de divulgación a los que por lo general no tienen acceso y son pocos. Irinea Buendía se ha convertido en uno de los nombres clave para entender la lucha de las madres de víctimas de violencias feminicidas en México. Y a pesar de que la intención no es cuestionar dicha impresión (de hecho, se suscribe la idea de que su lucha es ejemplar), parece que la construcción de empatías no es la misma para todas las oprimidas. La empatía se distribuiría con relación a "usos" particulares de la memoria, es decir, a establecer ciertos tipos de memorializaciones según momentos, necesidades e intenciones. La observación nace del tratamiento comparado que se hace de las historias de las mujeres víctimas en un espacio como el ммүт: ¿Cuál es la razón para contar la historia de Irinea con detalle y al mismo tiempo desechar las historias de las mujeres que hacen los performances en Ecatepec y otros municipios del Estado de México? Las ganancias sociales en cada caso son distintas. Mostrar la foto de Irinea al centro de la sala de exhibiciones, junto a un largo testimonio que los asistentes podían leer, sería también una manera de afirmar el discurso de la justicia del derecho del Estado, pues Irinea gracias su activismo consiguió un fallo de la Suprema Corte de Justicia de la Nación que permitió reabrir el caso de su hija Mariana, después de que las autoridades del Estado de México habían dado por cerrada la investigación. Su imagen y su palabra tendrían cabida porque constituyen una historia ejemplar, en algún sentido, dentro de la lógica y el discurso de la "igualdad de género" que abandera la modernidad, sobre todo desde el campo del derecho; mientras que las historias de las mujeres del Estado de México apenas son los testimonios de jóvenes pobres (anónimas) que no han conseguido ninguna sentencia o incidencia dentro del aparato estatal. Ante ello, la pregunta que surge es si se pueden desarrollar mecanismos de responsabilidad con las otras que sufren sin la necesidad de apropiarse de su dolor y su imagen para cumplir nuestros fines intelectuales.

Ello derivó en una sentencia emitida por la Suprema Corte de Justicia, la cual después de seis años del feminicidio de Mariana ordenó a las autoridades mexiquenses reabrir el caso (CIMAC,2018). 


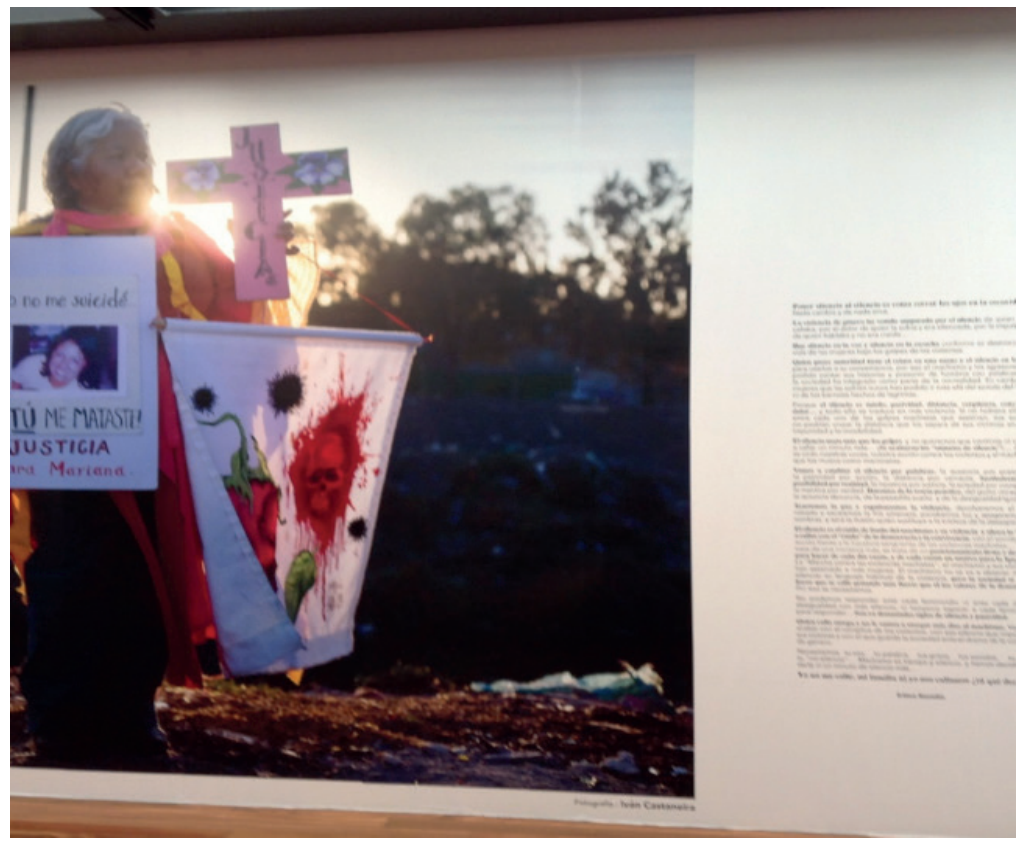

Figura 8. Fotografía de Irinea Buendía en la Exposición "Feminicidio en México" (2017). Museo Memoria y Tolerancia. Foto: José Ricardo Gutiérrez.

Con lo anterior no se desea dar a entender que quienes no han sufrido las violencias feminicidas no pueden aproximarse con cautela al sufrimiento de las víctimas, pues si bien las experiencias les pertenecen exclusivamente a las mujeres, la comprensión y la valoración de dichas experiencias van más allá de ellas. Esto no quiere decir, de ninguna manera, que se pueda prescindir de las mujeres para construir esa comprensión y valoración, pues el reconocimiento de su relato es reconocer la actualidad de la injusticia pasada, explicitando al menos dos cosas: 1) la capacidad actuante de las víctimas y 2) la lógica política que las puso en ese lugar de sufrimiento, es decir, el sistema estatal y social que desampara, silencia y maltrata las voces de las mujeres.

La injusticia sufrida por las víctimas de violencias feminicidas en México se gestaría no solo en la injuria infligida sobre sus cuerpos, también en la negación constante que se hace de su palabra. A lo que todo esto contribuiría es a la formación de una especie de "líderes de la memoria", como advierte José Carlos Agüero en su trabajo Los rendidos. Sobre el don de perdonar (2015). Esto no se afirma por Irinea Buendía, al final ella es una víctima que ha decidido emprender una lucha legítima, 
alimentada por su dolor y otras motivaciones, que hasta la fecha sigue vigente. Este liderazgo, en general, sería más bien encarnado por la figura del ммүт. Y es en ese liderazgo que se distingue el "uso" que hacen de las víctimas, su instrumentalización. La ganancia obtenida sería una suerte de "prestigio moral" que expresa un supuesto compromiso con el respeto a los derechos de las mujeres y la "igualdad de género".

\section{A manera de cierre}

En la última década, como nunca antes, las agendas gubernamentales, sociales, económicas, culturales y mediáticas se han visto copadas de discursos a favor de los derechos de las mujeres y la "igualdad de género"; sin embargo, la deuda con la mitad de la población humana del planeta sigue persistiendo con la prevalencia de brechas salariales, "techos de cristal", trabajos de cuidado no remunerados y un conjunto de violencias feroces que tan solo en México, según la onu (2018), le quitan la vida diariamente a un promedio de nueve mujeres. Ante ello, este trabajo ha intentado argumentar que la dificultad a la que nos enfrentamos no radica tanto en la enunciación pública del problema, sino en las maneras en que se ha comprendido y representado. Estos aspectos, junto a las desigualdades económicas, serán los que sigan alimentando la perpetuación de las violencias feminicidas, pues las formas hegemónicas de representación y comprensión que se han elaborado alrededor de dichas violencias han hecho a un lado las voces, experiencias y conocimientos de quienes las padecen: las mujeres. Con ello no se quiere sugerir que el reconocimiento a los relatos producidos por las mujeres vaya a cambiar por decreto la realidad que viven. Aunque la narración cuenta, la acción solidaria, compasiva y reparadora sigue prevaleciendo como clave para hacer justicia, con la condición de que sea, como ya se dijo de la mano de Arendt, una acción narrada. Por esa razón este trabajo se ha enfocado en elaborar una interpretación de la mirada construida por el ммут, mediante la exposición citada, para identificar los mecanismos que posibilitan la visibilidad/invisibilidad de los relatos de las mujeres.

Uno de los puntos principales sobre el que hace énfasis este artículo es la importancia de establecer una relación imagen/texto en el tratamiento mediático de las formas visuales de autorrepresentación de las mujeres víctimas de violencias feminicidas en México, pues de otra manera las formas en que ellas se autorrepresentan terminan por convertirse en la mera ilustración de los discursos legitimados. Para que las imágenes producidas por las víctimas puedan ser captadas en su valía, no bastaría con hacerlas circular en un periódico, un libro, un documental o una expo- 
sición. Es necesario también que vayan entrelazadas a la palabra de las víctimas y que esta ocupe un espacio donde pueda quedar manifiesta.

Con relación a este último punto, vale la pena considerar que la propuesta teórico-conceptual de este trabajo, articulada bajo algunos ejes como son la "colonidad del ver" (Joaquín Barriendos), los "usos" (Sarah Ahmed) y los espacios de aparición (Hanna Arendt), esto bajo un marco teórico más amplio que hace referencia al "conocimiento situado" (Donna Haraway) y al vínculo saber/poder (Michel Foucault), permite establecer un abordaje de las visualidades que producen las mujeres de la periferia y la manera en que esas narrativas son sometidas a un proceso de invisibilización y extractivismo epistémico por parte del ммут. Lo anterior no solo deriva en un señalamiento sobre la raíz moderno/androcéntrica de la mirada del museo, como se estableció a lo largo del artículo, sino que pone de relieve la necesidad de entender que el tratamiento de las fotografías de las mujeres de la periferia en la exposición discutida problematiza el lugar de la memoria en los procesos de reconocimiento de la palabra y la vida de las mujeres ante las violencias feminicidas en México, no solo como emblema de una causa que aspira a terminar con dicha violencia, también como acción. La memoria, entendida como acción, sería una operación transicional que permite ir construyendo un nuevo suelo en el que podamos encontrarnos, vivir. Es apelar a la memorialización no en su sentido monumentalista, que casi siempre termina por instrumentalizar a las víctimas. Más bien como una suerte de aprendizaje colectivo, inscrito en este caso en la triada memoria/imagen/ palabra, que ponga en el centro de sus intereses las experiencias y los relatos de las mujeres (víctimas).

La valía de abordar las narrativas y formas de representación visuales relativas a las violencias feminicidas en México radica en entender el peso y la importancia de dichos relatos en las maneras hegemónicas en que se concibe y, sobre todo, se reconoce la vida de las mujeres. Así, el debate no es si la vida de las mujeres se reconoce como un valor en sí mismo o no, sino la manera en que esas vidas son relatadas desde lo que revela su acción y su palabra. La vida, nos dice Julia Kristeva, recordando a Arendt, solo se realiza plenamente cuando "no cesa de interrogar tanto el sentido como la acción; la facultad de producir relatos a partir de la acción forma la fuente de la que brota el sentido, la inteligibilidad que penetra e ilumina la existencia humana" (Kristeva, 2013:5I). De ahí la necesidad de abordar las formas de representación que se hacen de las acciones de las mujeres de la periferia en la exposición "Feminicidio en México" (2017) del ммүт, pues nos permiten rastrear los modos en que las voces, los deseos, las imágenes, experiencias y relatos de estas mujeres son reconocidos a partir de su omisión dentro del museo. La clave para 
comenzar a desmontar las violencias feminicidas no está tanto en convencernos de que efectivamente las vidas de las mujeres son valiosas por sí mismas (aunque esto es sin duda un hecho), sino en las posibilidades de reconocer las formas en que las mujeres relatan sus vidas, desplegando un sentido y una realización política de su conocimiento/narración como parte vital de un mundo biosocial. En ese sentido, vale la pena subrayar que las mujeres que participan en los performances de la Red han podido hilvanar, colectivamente, una serie de conocimientos y experiencias en torno a las violencias feminicidas que predominan en el Estado de México, las cuales resultan pertinentes para el resto de la sociedad mexicana, pues la palabra y memoria que alumbran estas jóvenes mediante sus acciones contribuyen a elaborar una comprensión sobre las estructuras de dominación que caracterizan los modos de relacionalidad social y política en el contexto actual de la periferia urbana en México.

\section{Referencias:}

Agüero, José Carlos

2015 Los rendidos: Sobre el don de perdonar, Lima, Instituto de Estudios Peruanos.

Ahmed, Sara

2019 What's the use? On the uses of use, Estados Unidos, Duke University Press.

Amador, Manuel y Héctor Domínguez

2012 "Violencias y feminicidio en el Estado de México", en Patricia Ravelo y Héctor Domínguez (eds.), Diálogos interdisciplinarios sobre violencia sexual, Ciudad de México, ciesas.

Badiou, Alan

2004 "La idea de justicia", disponible en: http://www.catedras.fsoc.uba.ar/ heler/justiciabadiou.htm [consulta: 15/09/2016].

Barriendos, Joaquín

2008 "Apetitos extremos: la colonialidad del ver y las imágenes-archivo sobre el canibalismo de indias", Transversal, pp- I-I2 Consultado en: http:// eipcp.net/transversal/o708/barriendos/es

Barriendos, Joaquín

201 "La colonialidad del ver. Hacia un nuevo diálogo visual interepistémico", Nómadas, 35, pp. 13-29, en: http://nomadas.ucentral.edu.co/ index.php/inicio/I4-regimenes-de-visualidad-emancipacion-y-otre- 
dad-desde-america-latina-nomadas-35/135-la-colonialidad-del-ver-hacia-un-nuevo-dialogo-visual-interepistemico

Berger, John

2000 Modos de Ver, Barcelona, Gustavo Gili.

CIMAC

2018 "Reconocimiento Don Sergio Méndez Arceo a Irinea Buendía". cimacNoticias, disponible en: https://cimacnoticias.com.mx/noticia/reconocimiento-don-sergio-mendez-arceo-para-irinea-buendia/ [consulta: I9/II/2020].

Felski, Rita

1995 The gender of modernity, Massachusetts, Harvard University Press.

Fernández, Estela

2012 "Introducción”, en Estela Fernández y Gustavo Silnik (eds.), Teología profana y pensamiento crítico, Buenos Aires, ciccus/clacso, pp. 13-25.

Fernández, Emilio

2018 "Vivir en Ecatepec. Entre inseguridad y pobreza", El Universal (Io/ıo/20I8), disponible en: https://www.eluniversal.com.mx/ metropoli/ecatepec-sumido-en-la-pobreza-y-violencia [consulta: 29/03/2019].

Foucault, Michel

2006 Las palabras y las cosas: una arqueología de las ciencias bumanas, Madrid, Siglo xxi Editores.

Foucault, Michel

2009 Vigilar y castigar. Nacimiento de la prisión, Ciudad de México, Siglo xxI Editores.

Fricker, Miranda

2017 Injusticia epistémica, Barcelona, Herder.

Grosfoguel, Ramón

2016 "Del extractivismo económico al extractivismo epistémico", Revista Internacional de Comunicación y Desarrollo, 4, pp. 33-45, doi: I0.25058/20112742.60

Harding, Sandra

1996 Ciencia y feminismo, Madrid, Ediciones Morata.

Haraway, Donna

2003 "Situated knowledges: The Science Question in Feminism and the Privilege of Partial Perspective", en Sandra Harding (ed.), The Feminist 
Standpoint Theory Reader: Intellectual and Political Controversies, Nueva York, Routledge, pp 8I-I03, doi: 10.2307/3178066

Infobae

2020 "Feminicidios en México: el 63\% de los asesinatos de mujeres fueron cometidos por el crimen organizado". Infobae, disponible en: https://www.infobae.com/america/mexico/2020/07/o9/feminicidios-en-mexico-el-63-de-los-asesinatos-de-mujeres-fueron-cometidos-por-el-crimen-organizado/?fbclid=IWAR25B GaTr_Apl8RIKFornOiwiZgrL9olkuolNlmgjco4nVilzexVkgtfoxm [consulta: $23 / \mathrm{II} / 2020]$.

Kristeva, Julia

2013 El genio femenino. 1. Hannah Arendt, Buenos Aires, Paidós.

Levinas, Emmanuel

2004 La Teoría Fenomenológica de la Intuición, Salamanca, Sígueme.

Mignolo, Walter

2017 El museo en el horizonte colonial de la modernidad, disponible en: https:// www.youtube.com/watch?v=4maQRDgixzs [consulta: 15/04/2020].

Mondragón, Rafael y Manuel Amador

2020 "La construcción de una ciencia popular y plebeya”, en M. Amador y R. Mondragón (eds.), Vida que resurge en las orillas. Experiencias del Taller Mujeres, Arte y Política en Ecatepec, Ciudad de México, Heredad.

Museo Memoria y Tolerancia

2017 Feminicidio en México ¡Ya Basta!, México, Museo Memoria y Tolerancia.

Núñez, Guillermo

2004 "Los hombres y el conocimiento. Reflexiones epistemológicas para el estudio de los hombres como sujetos genéricos", Desacatos, I5-16, pp. I3-32, doi: 10.29340/16.1069

Organización de las Naciones de Unidas (onU) Mujeres-México

20I8 La violencia contra las mujeres no es normal ni tolerable. Garantizar los derechos bumanos de las mujeres y las niñas es trabajo de todas y de todos, México, Organización de las Naciones Unidas.

Pateman, Carole

1980 "The Disorder of Women: Women, Love, and the Sense of Justice", Ethics, 9I(I), pp. 20-34, doi: 10.1086/292200

Phillips, Anne

2018 "Gender and Modernity", Political Theory, 46(6), pp. 837-860, doi: I0.1177/0090591718757457 
Rancière, Jacques

2007 El viraje ético de la estética y la política, Santiago, Palinodia.

Rosaldo, Michelle

1980 "The uses and abuses of Anthropology: reflections of feminism and cros-cultural understanding", Signs, 5 (3), pp. 389-4I7, doi: IO.1086/493727

Rojas, Ana

2018 "Monstruo de Ecatepecः ¿Por qué este municipio de México es el más peligroso para ser mujer?", $в$ вВ mundo, disponible en: http://www.bbc. $\mathrm{com} / \mathrm{mundo} /$ noticias-america-latina-45821520 [consulta: oI/04/2019].

Segato, Rita

2007 La Nación y sus Otros, Buenos Aires, Prometeo.

Segato, Rita

2016 La guerra contra las mujeres, Madrid, Traficantes de Sueños.

Vázquez, Rolando

2018 "El museo, decolonialidad y el fin de la contemporaneidad", Otros Logos. Revista de Estudios Críticos, 9, pp. 46-6I, consultado en: http://www. ceapedi.com.ar/otroslogos/Revistas/ooog/5_2018_Vazquez_II.pdf

José Ricardo Gutiérrez Vargas

Investigador asociado C de tiempo completo en el Centro Regional de Investigaciones Multidisciplinarias (CRIM), de la Universidad Nacional Autónoma de México, en los programas "Equidad y género" y "Cultura, política y diversidad". Doctor en Humanidades por el King's College London (University of London) con una investigación sobre el cruce epistémico entre imagen, memoria, justicia y género en los discursos visuales del feminicidio en México. Sus líneas de investigación son: cultura visual y género; vínculo memoria social/justicia/performance; fundamentos sociales, antropológicos y filosóficos del debate feminista contemporáneo; estrategias políticas y pedagógicas contra las violencias feminicidas en América Latina. Ha sido docente en universidades como la University of London, Universidad Autónoma de la Ciudad de México y el Instituto Tecnológico de Estudios Superiores de Monterrey. Cuenta con varias publicaciones en revistas especializadas y ha participado en diversos seminarios, conferencias y congresos en Europa, Canadá y América Latina enfocados en los debates actuales de género, violencia, imagen, memoria y performance. 
Citar como: José Ricardo Gutiérrez Vargas (2022), "Género y mirada: la invisibilización del conocimiento producido por las mujeres en México", Iztapalapa. Revista de Ciencias Sociales y Humanidades, núm. 92, año 43, enero-junio de 2022, ISSN: 2007-9176; pp. 157-I88. Disponible en <http:// revistaiztapalapa.izt.uam.mx/index.php/izt/issue/archive $>$. 